Open Access

\title{
Estimating farmers' willingness to pay for weather index-based crop insurance uptake in West Africa: Insight from a pilot initiative in Southwestern Burkina Faso
}

\author{
William M. Fonta ${ }^{1 *}$, Safietou Sanfo ${ }^{1}$, Abbi M. Kedir ${ }^{2}$ and Djiby R. Thiam³
}

\author{
* Correspondence: fonta.w@wascal. \\ org; wf2228@columbia.edu \\ 'West African Science Service \\ Centre on Climate Change and \\ Adapted Land Use (WASCAL), \\ Competence Center, Blvd \\ Mouammar Kadhafi, 06, \\ Ouagadougou, BP 9507, Burkina \\ Faso \\ Full list of author information is \\ available at the end of the article
}

\begin{abstract}
Weather index-based crop insurance is increasingly becoming important as a risk mitigation strategy that farmers may use to mitigate adverse climate shocks and natural disasters encountered during farming. While Europe, North America, and Asia account for $20.1 \%, 55 \%$, and $19.5 \%$ of the total agricultural insurance premium worldwide, respectively, Africa accounts for only $0.5 \%$ of the world insurance industry. One of the key reasons advanced against the low index insurance participation rate in Africa is the failure to involve farm households at the initial conceptualization and design of pilot initiatives. Therefore, the main purpose of this paper is to design an improved participatory methodology that could help elicit information on the value placed by farm households in Southwestern Burkina Faso on a new weather index-based crop insurance management initiative. A key concept in the improved participatory methodology is that of the willingness to pay (WTP) of farm households for the scheme. Knowledge of the maximum amount that farmers are willing to pay for the scheme can help insurance policy providers and public policy makers to design and put in place measures that sustain index insurance schemes in a developing country context and improve welfare among participating farmers.
\end{abstract}

Keywords: Climate change, Agricultural risk, Adaptation strategy, Weather index-based crop insurance, Contingent valuation method, Willingness to pay, Heckman 2-step estimator

\section{Background}

West Africa is generally recognized as one of the regions in the world most vulnerable to the impacts of climate change (CC) but with the least adaptation and mitigation capacities (IPPC 2014). The situation is made worse by the fact that agriculture is the main source of livelihood for more than $60 \%$ of the population. However, it is still mainly rain-fed, practiced on relatively fragile soils, with extensive farming, and with very little use of modern inputs and improved farming techniques (Kurukulasuriya and Mendelsohn 2008). By 2030, two thirds of the population in West Africa (i.e., Benin, Togo, Ghana, Cote d'Ivoire, the Gambia, Senegal, Mali, Burkina Faso, Niger, and Nigeria) are predicted to grow from 320 to 475 million (about $6 \%$ of world's population) [WASCAL 2015]. Although most of the growth is predicted for urban areas, the 
estimated 48\% living and working in rural areas will face the challenge of food insecurity for themselves as well as for the ever increasing urban population. According to the Montpellier Panel (2013), without positive productivity changes, food production systems in West Africa will only be able to meet $13 \%$ of the needs in 2050. Under moderate CC and without adaptation, total agricultural production in West Africa will even decline by at least $1.5 \%$. Most of the food demand is satisfied from food imports, which are not cheap. In addition, the food import bills often worsen the current account deficit due to persistent negative trade balance which leads to macroeconomic distortions.

It is therefore not surprising that many economists, policy makers, development partners, development finance groups, and research institutions in Africa are now exploring innovative ways that promote climate smart agricultural (CSA) practices. For example, the African Development Bank Group (AfDB), in collaboration with Positive Planet, has taken concrete steps to develop strategies that support institutional and research capacities that promote microfinance innovation in agriculture. In fact, many West African nations have started introducing weather-based agricultural crop insurance schemes in their development visions. These include, for example, Mali and Burkina Faso, which are currently piloting an index-based crop insurance (IBCI), for cotton and maize; Benin for maize; and Senegal for groundnut and maize (Muller 2012).

As discussed extensively in the literature on adaptation to risks associated with CC (e.g., Barnett and Mahul 2007; Mahul and Skees 2007; Barnett et al. 2008; Giné et al. 2008; Yang 2009; Giné and Yang 2009; Clarke and Dercon 2009; Mahul and Stutley 2010; IFAD 2011; MCII 2013; Cole et al. 2013; Karlan et al. 2014; CCAFS 2014; Smith and Watts 2014), index-based crop insurance represents a very promising agricultural risk management strategy that farmers may use to mitigate adverse climate hazards and natural catastrophes encountered during farming activities. In many parts of the world, various experiences show that implementation of index-based crop insurance policies have been used to support farmers to limit the losses that natural calamities like droughts, floods, variabilities in rainfall drought, flood, variability in temperature, dry spells, hail, and heat waves might cause to crop yields and household income (Kunreuther 1996; Food and Agricultural Organization 2011; Barnett 2014; Patt et al. 2010). For instance, in Kenya, the mobile technology is being used to support farmers through crop insurance. Insurance claims are triggered by data from local weather stations and are distributed in the form of mobile money. Farmers with land as little as 1 acre can use their assets as collateral for this crop insurance via mobile headsets. The mobile technology has tremendous potential to chart the future expansion of such an innovative crop insurance scheme in the rest of the continent where road accessibility is very limited and weather data precarious, despite the rise of local weather stations in some countries in the continent.

Some of the merits of index-based crop insurance are: (i) it minimizes the longstanding contract problems such as moral hazard/hidden action and adverse selection/ hidden information as the index read from weather stations is exogenous and cannot be tampered with the intervention of participating farmers (Barnett and Mahul 2007; Barnett et al. 2007; Devereux and Guenther 2009); (ii) in the case of crop damage, it makes faster payouts, which means that farmers will not have to sell assets or depend on emergency food aid to survive during climate shocks (CCAFS 2014); (iii) insured households are more likely to invest on agricultural inputs leading to higher outputs 
and income per unit of land (Sundar and Ramakrishnan 2013); and (iv) it enhances farmers' ability to withstand and recover from adversity, therefore strengthening resilience of communities as well as assisting them to get out of the vicious circle of poverty and improve household welfare (World Bank 2005; Berg et al. 2009; De Bock and Gelade 2012; Koloma 2015).

However, despite the merits associated with crop insurance schemes, its coverage and uptake in West Africa, as in many other developing countries, remain still low (Muller 2012). For example, in Burkina Faso, it has been observed that less than 10\% of farmers have fully enrolled in the ongoing pilot initiatives. Although no consensus has emerged as to why this is so, some of the possible reasons advanced by many crop insurance experts include: (i) difficulties in dealing with climate features, particularly the problem of huge spatiotemporal rainfall variability, which is often used as weather-based index for designing pilots-also called spatial basic risk (Berg et al. 2009; Ibrahim et al. 2014; Fonta et al. 2017); (ii) difficulty to solve the trade-offs between level of protection and cost of insurance premium (Berg et al. 2009; Muller 2012; Koloma 2015); (iii) lack of stakeholders involvement in analyzing insurance products and policies (van Asseldonk et al. 2013; Muller 2012); (iv) poor understanding of the concept of crop insurance, inability to pay premiums, as well as rigid enrolment criteria (van Asseldonk et al. 2013; Planet Guarantee 2014); (v) uncertainty in cash flows as many banks and large microfinance institutions (MFIs) are very reluctant to finance agriculture through small microfinance institutions (MFIs) and cooperatives (Koloma 2015; Planet Guarantee 2015); and finally, (vi) poor understanding of famers' risk perception in general, their willingness to pay, and the factors that influence their decision to pay such as low level of trust in insurance providers.

While these limitations may be specific to West Africa, the general literature on weather index-based insurance highlights other important limitations (see, for example, Smith and Glauber 2012; Mahul and Stutley 2010; Goodwin 2003; Miranda 1991; Jensen and Barrett 2016). First, widespread participation in agricultural insurance requires strong public support through the provision of subsidies. As noted in Smith and Glauber (2012), most crop insurance products would hardly exist in the absence of subsidies. For example, experiences from USA show that subsidies not only allow for participation in agricultural insurance, but they also correct the problem of adverse selection faced by insurance companies (Smith and Glauber 2012). Second, participation in agricultural insurance is driven by the problems of asymmetric information. Both moral hazard (i.e., hidden action by farmers) and adverse selection (i.e., hidden information) affect demand and supply of index-based crop insurance. However, Chambers (1989) and Fafchamps (2010) show that risk sharing might contribute to reducing the problem of moral hazard. For instance, when farmers bear part of the cost that is associated with the loss experienced, they become more cautious about the implications of potential losses that affect their assets. In such circumstances, farmers are usually more willing to take actions that may reduce the probability of occurrence of the insured loss.

Third, the problem of basic risk faced by farmers also influences the demand for insurance services. Farmers might experience losses that are not correlated with the insured index. Therefore, despite the real advantages that might be gained in participating in crop insurance, some essential conditions must be met within a country in order for farmers to truly benefit from insurance services. For example, the presence of good and 
well-functional physical and institutional infrastructures must be present in a country to allow farmers to make their claims and private insurance companies verify their losses. These may include good roads, well-functioning regulatory structures, rules of law, and product delivery mechanisms, among others. Lastly, other minor challenges include wealth and liquidity constraints and religious and cultural beliefs, among others. As reported in Janzen et al. (2013) and Dercon and Christiaensen (2011), poor farmers remain less likely to have the wealth and liquidity that is needed to purchase insurance policies. Jensen and Barrett (2016) highlight the barriers associated with religious and cultural beliefs. For instance, in northern Kenya, insurance schemes that did not comply with Sharia law (Islamic religious law) were not initially well accepted in the region (Jensen and Barrett 2016). Finally, there is also a risk of increased premium payments and also insurers withdrawing support in the face of increasing likelihood of crop failure (Tucker 1997; Mills 2007; Duncan and Myers 2000).

These problems, while significant, are not without solutions. For instance, Muller (2012), Fuchs and Wolff (2011), Kapphan (2011), Clarke and Dercon (2009), Barnett et al. (2008), and Barnett and Mahul (2007) emphasized the importance of farmers' involvement in the initial design and conceptualization of insurance schemes as one way of resolving the challenge of low participation in index insurance by farmers. The main purpose of this paper is therefore to design an improved participatory methodology that could help elicit information on the value placed by farmers in Southwestern Burkina Faso on a new weather index-based crop insurance management initiative. The scheme is a joint initiative of the Planet Finance Group and the Global Index Insurance Facility (GIIF) program of the World Bank. This will help inform the design of appropriate household insurance premiums or levies. A key concept in such an improved participatory methodology is that of the WTP for the pilot initiative. Knowledge of the maximum amount that farmers are WTP for the scheme will help Planet Finance Group, donor agencies, and the Government of Burkina Faso to consider the introduction of subsidies in order to help sustain the pilot initiative in the area and the country. This will be critical for compensating farmers for the loss they experience.

\section{Agricultural crop insurance in Burkina Faso and the nature of the new pilot initiative}

The importance of agricultural crop insurance as a risk mitigation strategy to climate change in Burkina Faso was first highlighted in the country's National Adaptation Plan of Action (NAPA). However, it was the Joint Ministerial Decision $\mathrm{N}^{0} 2012 \mathrm{MAH} /$ MRA/MEDD/MEF/MICA/MASSN/MATD of 2012 that formally set the stage for its operationalization and implementation in the country. However, prior to the decision, the first pilot initiative in the country (i.e., Satellite-based weather index insurance) took off in early 2011 by PlaNet Guarantee which mainly targeted maize and cotton farmers (Planet Guarantee 2014). Similar to many existing crop insurance pilot schemes in Sub-Saharan Africa (SSA), yield losses are not directly measured in the fields of insured farmers. Rather, they are indirectly assessed through the value of an index (decadal relative evapotranspiration), which is measured through remote sensing approaches (i.e., EARS method) [Muller 2012].

Farmers receive indemnity/compensation whenever relative evapotranspiration falls below $5 \%$ of historical long-running decadal relative evapotranspiration data. The threshold for full 
payment is adjusted depending on areas and crop development period. The payouts are dependent on three specific periods that mimics the different stages of maize production. That is, the first stage that covers 30 days after seeding (1st of July), the second stage that covers 20 days thereafter, and the last stage covering the last 40 days of maize production (in total 90 days). Thus, the payouts that are proportional to the total covered amount for the three subsequent stages are 30\%, 20\%, and 40\%, respectively (van Asseldonk et al. 2013). Insurance premiums are usually tied to credit facilities but, on the average, farmers pay as much as $10.8 \%$ of the value of insured inputs plus an insurance tax of $8 \%$ (taking it to 18 . $8 \%)$. In 2014, there were over 8281 clients enrolled in the country (PlaNet Guarantee 2015).

In order to further expand the experience with new products/crops such as cotton, sorghum, millet, and groundnut and include new technical partners (delivery channels) in various target localities, PlaNet Guarantee felt it was critical to understand farmers' WTP for the new initiative in Southwestern Burkina Faso, as well as factors that drive the demand for farmers' uptake. Thus, as part of the effort to support the implementation of the new pilot initiative in Southwestern Burkina Faso, it was decided to carry out a contingent valuation method (CVM) study to capture the willingness to pay (WTP) of farm households in the region. Therefore, this study follows the conceptual framework underlined in McCarter (2003) and Sarris et al. (2006) to study WTP for crop insurance in Morocco and Tanzania, respectively. In doing so, we add new insights to the current literature and describe the extent to which socioeconomic variables, farming practices, and farmers' behaviors influence WTP for crop insurance in an African context.

\section{Methods}

\section{The analytical framework}

We adopt the contingent valuation method (CVM), which is one of the most widely used participatory methods, for estimating the total economic value (TEV) of many classes of environmental goods and services that are not easily tradable in markets. CVM is appealing because its results are relatively easy to interpret. For instance, WTP estimates can be represented in terms of mean/median values per household or aggregate values for the relevant population of interest (Fonta et al. 2008).

The theoretical basis of the method is deeply rooted in two well-known monetary measures of welfare changes in neoclassical welfare economics. That is, the Hicksian Compensating Variation (CV) and Equivalent Variation (EV) measures of welfare changes. For illustrative purposes, let us consider the welfare changes to an individual (consumer) resulting from a proposed new policy plan (e.g., environmental improvement). Let $W_{i}^{0}$ denote the pre-policy intervention (or status quo) level of welfare and $W_{i}^{1}$ the ex-post level of welfare. Also, let $W_{i}^{0} \equiv\left(y_{i}^{0}, P^{0}\right)$ and $W_{i}^{1} \equiv\left(y_{i}^{1}, P^{1}\right)$ represent the budgets that measure prices $(p)$ and incomes $(y)$ faced by consumer $i$ under the new policy plan. Therefore, the transition from status quo level to post-policy intervention level is simply the difference in the indirect utility given as:

$$
v\left(y_{i}^{1}, P^{1}\right)-v\left(y_{i}^{0}, P^{0}\right)
$$

Consumer $i$ will accept the change caused by the new policy plan if $v\left(y_{i}^{1}, P^{1}\right)-v\left(y_{i}^{0}, P^{0}\right)$ $>0$. On the other hand, the consumer will reject the plan if $v\left(y_{i}^{1}, P^{1}\right)-v\left(y_{i}^{0}, P^{0}\right)<0$. This 
represents the participation constraint. However, since most policy makers are essentially interested in the actual dollar worth of a proposed new policy intervention, it is often convenient to adopt a money metric approach to quantifying the resulting change in welfare (Varian 1992). The simplest approach is to adopt the minimum expenditure function, which is dual to the indirect utility function as highlighted in Haab and McConnell (2002). That is, $m(q ; y, P)$ which tells us how much money individual $i$ would need at a vector of prices $q$ to be well off as he or she would be facing prices $P$ having income $y$ Based on this, Eq. (1) can be written as:

$$
m\left(q ; y_{i}^{1}, P^{1}\right)-m\left(q ; y_{i}^{0}, P^{0}\right)
$$

If the change between the status quo and the post-policy intervention levels occurs only in terms of a price change, say for example $q \equiv P^{0}$ or $q \equiv P^{1}$, this leads to the $\mathrm{CV}$ and EV measures of welfare changes, respectively (Mas-Colell et al. 1995). They are, respectively, defined as:

$$
\begin{aligned}
& \mathrm{EV}=m\left(P^{0} ; y_{i}^{1}, P^{1}\right)-m\left(P^{0} ; y_{i}^{0}, P^{0}\right)=m\left(P^{0} ; y_{i}^{1}, P^{1}\right)-y_{i}^{0} \\
& \mathrm{CV}=m\left(P^{1} ; y_{i}^{1}, P^{1}\right)-m\left(P^{1} ; y_{i}^{0}, P^{0}\right)=y_{i}^{1}-m\left(P^{1} ; P^{0}, y_{i}^{0}\right)
\end{aligned}
$$

Equation (3) is the Hicksian Equivalent Variation (EV) measure of a welfare change. When it is greater than zero, the policy plan results in an improvement in welfare, and vice versa. In other words, if $E V>0$, Eq. (3) represents the amount of money an individual is willing to accept (WTA) from the policy planner in order to forgo the improvement from $W_{i}^{0}$ to $W_{i}^{1}$. If $\mathrm{EV}<0$, Eq. (3) indicates the amount of money an individual is willing to pay not to switch to the ex-post deteriorating level of welfare $W_{i}^{1}$. Similarly, Eq. (4) represents the Hicksian Compensating Variation (CV) measure of a welfare change. It tells us how much money would be taken away from consumer is income, in her new level of welfare $W_{i}^{1}$, in order to make her indifferent between $W_{i}^{0}$ and $W_{i}^{1}$. In absolute terms, Eq. (4) represents the consumer's WTP to be at $W_{i}^{1}$, or the amount of money a consumer is WTA from the policy planner to remain at the new deteriorating level of welfare $W_{i}^{1}$.

Generally, the choice of which technique to use largely depends on the valuation problem at hand or the type of policy intervention proposed. If the goal of the new policy plan is to arrange for a compensation scheme at the new price $P^{1}$, then the $\mathrm{CV}$ is the most appropriate welfare measure. However, if the goal is to arrange for a benefit scheme at the new price, then the EV measure is the most appropriate option (Fonta et al. 2008, 2010a, b). This relationship is shown in Table 1.

Equations (3) and (4) are essential to what a properly framed CVM study seeks to estimate. It is usually done through the construction of a credible CV scenario. The scenario

Table 1 Relation between EV, CV, WTP, and WTA

\begin{tabular}{lll}
\hline & EV measure & CV measure \\
\hline Utility increases & WTA & WTP \\
Utility decreases & WTP & WTA \\
\hline
\end{tabular}

Source: Adopted from Haab and McConnell (2002) 
describes the nature of the proposed new policy intervention plan, the hypothetical level of welfare $W^{1}$, the institutional setting in which the proposed policy plan will be provided, and the manner in which each consumer will have to pay for financing the new plan. The CV scenario is then presented to a sample of representative consumers through face-face interviews, recording their WTP or WTA values for the intervention plan. Several value elicitation formats have been proposed and used in the CVM literature. These include, the open-ended approach, the bidding game technique, the payment card approach, the singleor double-bounded referendum (dichotomous) formats, as well as the recently proposed stochastic payment card design (see, for example, Mitchell and Carson 1989; Freeman 1992; Fonta et al. 2010a).

\section{The sample selection WTP model}

The choice of an appropriate econometric model depends largely on the elicitation format used in the CVM design. In this study, the dichotomous choice (DC) or referendum format buttressed with an open-ended (OE) follow-up elicitation question is used. Besides being highly incentive-compatible, this method provides far more information on WTP and information on plausibility of responses than the other alternative value elicitation approaches (Greene et al. 1995). Additionally, DC helps improve the precision of the WTP estimates since a follow-up question has been introduced after the referendum, as highlighted in Arrow et al. (1993). This reduces the problem of unfamiliarity with the market scenario (Mekonnen 2000). In fact, DC is very close to what the respondents are familiar with as it mimics a typical bargaining process in which the respondents first reject the offered price and then state their maximum WTP.

To analyze the DC question buttressed with an $\mathrm{OE}$ follow-up elicitation question, a two-step estimation procedure was adopted. In the first stage, a probit model is used to determine households' decisions to participate (i.e., the participation/selection model). In the second stage, an OLS estimation technique is run for the subsample of respondents with positive WTP values (i.e., the primary equation). This is based on the assumption that when an individual decides to participate, he or she would provide a positive WTP value (valuation model). Formally, let $Y_{1}$ denote the farmers' maximum WTP amount for the scheme, $Y_{2}$ a binary variable taking the value of 1 if an individual decides to participate in the scheme and 0 otherwise. Let $u$ and $v$ represent the matrices of explanatory variables corresponding, respectively, to the participation and valuation model as shown in Table 2. Then, we can write:

$$
\ln Y_{1 i}=u_{i}^{\prime} \alpha+\alpha \mu_{i}
$$

for the $(\log )$ of WTP equation, where $\sigma$ is a scale factor, $Y_{1 i}$ is a binary variable observed only when $Y_{2 i}=1$ (i.e., if the farmer participates in index insurance), and

$$
Y_{2 i}=1 \text { if } v_{i}^{\prime} \beta+\varepsilon_{i} \geq 0, \text { and } Y_{2 i}=0 \text { if } v_{i}^{\prime} \beta+\varepsilon_{i}<0
$$

for the participation model, where $\mu_{i}$ and $\varepsilon_{i}$ are the error terms that are assumed to be bivariate normal with zero means, variances equal to 1 and correlation coefficient $\rho$. Note that when $\rho=0$ the two decisions are independent and the parameters of the two equations can be estimated separately. However, if $\rho \neq 0$, the two decisions are not 
Table 2 Sample statistics

\begin{tabular}{|c|c|c|c|c|}
\hline Variable & Definition and measurement & $\begin{array}{l}\text { Cor. } \\
\text { with } \mid \mathrm{BCl}\end{array}$ & $\begin{array}{l}\text { Mean/ } \\
\text { proportion* }\end{array}$ & Std. Dev. \\
\hline $\begin{array}{l}\text { Positive WTP (Dep. Var. } \\
\text { in probit analysis) }\end{array}$ & $\begin{array}{l}1 \text { if WTP }>0 \text {, and } 0 \text { otherwise ( } 1 \text { for a yes } \\
\text { answer to the starting bid offered in the } \\
\text { DC question, and } 0 \text { otherwise) }\end{array}$ & & 0.88 & 0.32 \\
\hline $\begin{array}{l}\text { Willingness to pay } \\
\text { (Dep. Var. in the OLS } \\
\text { estimation) }\end{array}$ & $\begin{array}{l}\text { Maximum WTP in FCFA monthly } \\
\text { (i.e., households maximum WTP amounts } \\
\text { elicited in the OE follow-up elicitation question) }\end{array}$ & & 6364.2 & 6885.0 \\
\hline Starting_bid & $\begin{array}{l}\text { The initial bid amount offered to the } \\
\text { respondent in the DC question and } \\
\text { ranged between } 2538 \text { CFA }(\$ 5.1) \\
\text { and } 17,500 \text { CFA ( } \$ 47.0)\end{array}$ & - & 6409.6 & 6010.7 \\
\hline Age & Age of respondent (years, most recent birthday). & \pm & 46.6 & 14.1 \\
\hline Access_credit & $\begin{array}{l}\text { Indicating whether or not an individual } \\
\text { has access to formal credit facilities } \\
(1=\text { access, } 0 \text { otherwise })\end{array}$ & + & $0.11^{*}$ & \\
\hline Access_irrigation & $\begin{array}{l}\text { Indicating whether or not an individual } \\
\text { makes frequent use of supplementary } \\
\text { irrigation technique ( } 1=\text { make } \\
\text { frequent use, } 0 \text { otherwise) }\end{array}$ & \pm & $0.43^{*}$ & \\
\hline Confidence & $\begin{array}{l}\text { Indicating whether or not an individual } \\
\text { has confidence in microfinance institutions } \\
\text { designated as fund manager for the } \\
\text { Scheme ( } 1=\text { confident, } 0 \text { otherwise) }\end{array}$ & + & $0.77^{*}$ & \\
\hline Cost_estimate & $\begin{array}{l}\text { Annual cost of crops damage to } \\
\text { household during the last } 12 \text { months } \\
\text { (in CFA per Hectare) }\end{array}$ & + & $194,832.3$ & $311,592.6$ \\
\hline Crop_diversity & $\begin{array}{l}\text { Indicating whether or not an individual } \\
\text { engages in crop diversity as an } \\
\text { adaptation strategy to climate } \\
\text { risk ( } 1=\text { engages, and } 0 \text { otherwise })\end{array}$ & \pm & $0.63^{*}$ & \\
\hline Education & Number of years of schooling & + & 2.6 & 3.7 \\
\hline Farm_activities & $\begin{array}{l}\text { Work on farm activities or not } \\
(1=\text { work, } 0 \text { otherwise })\end{array}$ & + & $0.98^{*}$ & \\
\hline Farming_experience & Number of years of farming experience & + & 31.1 & 15.1 \\
\hline Farm_size & Household farm size (in hectares) & + & 1.6 & 1.5 \\
\hline Gender & 1 if male, and 0 otherwise & \pm & $0.92^{*}$ & \\
\hline Household_income & $\begin{array}{l}\text { Sum of household income from farm and } \\
\text { nonfarm activities (last } 12 \text { months in CFA) }\end{array}$ & + & $163,552.9$ & $159,764.8$ \\
\hline Household_size & $\begin{array}{l}\text { All members living and feeding commonly } \\
\text { from same source }\end{array}$ & + & 11.6 & 10.4 \\
\hline Knowledgeable_risk & $\begin{array}{l}\text { Indicating whether or not an individual has } \\
\text { basic knowledge about climate change } \\
\text { risks to agriculture ( } 1 \text { = aware, } 0 \text { otherwise) }\end{array}$ & + & $0.87^{*}$ & \\
\hline Knowledgeable_insurance & $\begin{array}{l}\text { Indicating whether or not an individual is } \\
\text { knowledgeable about crop insurance in } \\
\text { general ( } 1 \text { = knowledgeable, } 0 \text { otherwise) }\end{array}$ & + & $0.32^{*}$ & \\
\hline Social_capital & $\begin{array}{l}\text { Whether or not an individual received support } \\
\text { from friends, relatives, or through group } \\
\text { membership to cope with climate risks } \\
\text { in the last } 12 \text { months prior to survey } \\
\text { ( } 1=\text { received, and } 0 \text { otherwise). }\end{array}$ & \pm & $0.39^{*}$ & \\
\hline
\end{tabular}

independent and the parameters of the two equations should be estimated jointly (Strazzera et al. 2003). Additionally, since the unobservables affecting the participation decision are more likely to be correlated with the unobservables that drive the amount 
of money that farmers are willing to pay for the scheme, Eqs. (5) and (6) have been estimated jointly using Heckman's 2-step estimator as follows (Heckman 1977; Maddala 1983; Köhlin 2001; Greene 1993; Fonta et al. 2010b). Firstly, note that the conditional expected value of $Y_{1 i}$ is given as:

$$
E\left[\ln Y_{1 i} \mid Y_{2 i}=1\right]=u_{i}^{\prime} \alpha+\rho \sigma \lambda\left(v_{i}^{\prime} \beta\right) .
$$

where $\lambda\left(u_{i}^{\prime} \alpha\right)=\phi\left(v_{i}^{\prime} \beta\right) \mid \Phi\left(v_{i}^{\prime} \beta\right)$ is the inverse of the Mills ratio and $\phi$ and $\Phi$ are the standard normal density and standard normal functions, respectively. The first step of Heckman's approach is to estimate the participation equation using a probit model, which generates an estimate of $\lambda$. The second step entails an ordinary least squares (OLS) regression for only the subsample of farmers with positive WTP responses of $Y_{1 i}$ (i.e., valuation equation) on $x$ and $\hat{\lambda}$.

\section{Data collection}

The study was primarily designed to meet the policy challenge of improving farmers' resilience to climate change impact through crop insurance implementation. The data were collected from the southwestern administrative region of Burkina Faso, which is a pilot location for a proposed new index-based crop insurance management initiative proposed by PlaNet Guarantee. The region is located between the 700 and $1100 \mathrm{~mm}$ isohyets and subject to severe dry spells within the rainy season (Ibrahim et al. 2014). The length of the growing period is quite variable, ranging from 70 to 100 days/year. The overall population density of the region is around 70 inhabitants per square $\mathrm{km}$. This is quite high when compared with Burkina Faso's average population density of 50 inhabitants per square $\mathrm{km}$. Agriculture, livestock, and fisheries are the main economic activities in the region and provide employment to about $75.4 \%$ of the total work force.

The study was undertaken in ten villages in Southwestern Burkina Faso (Fig. 1). Selection of the villages was based on public enlightenment campaigns that focused on agricultural crop insurance coverage carried out in these villages by PlaNet Guarantee. The data were collected between May and June 2014, using two complementary approaches: focus group discussions (FGDs) and quantitative surveys with household-level questionnaires. The FGDs were mainly used to construct the crop insurance management scenario including other important CC information that could not be obtained through household questionnaires. The household survey focused mainly on the collection of primary data on farm household-level variables including the crop insurance management scenario under which the evaluation took place. It was presented to the respondents in the following form:

We would like to ask you a number of questions related to the potential of introducing a new index-based crop insurance scheme in Southwestern Burkina Faso by PlaNet Guarantee. The nature of the proposed scheme is as follows: you pay a fixed amount of money for the next one year (an insurance premium) to a designated microfinance institution working with PlaNet Guarantee to cover your crops against dry spells during sowing and maturity. This amount could be paid weekly, every two weeks, or monthly depending on your preferred payment frequency and the type of insurance contract entered into. Only in the case of an officially acknowledged dry spell occurrence that you will get compensated for any losses incurred on your farms. 


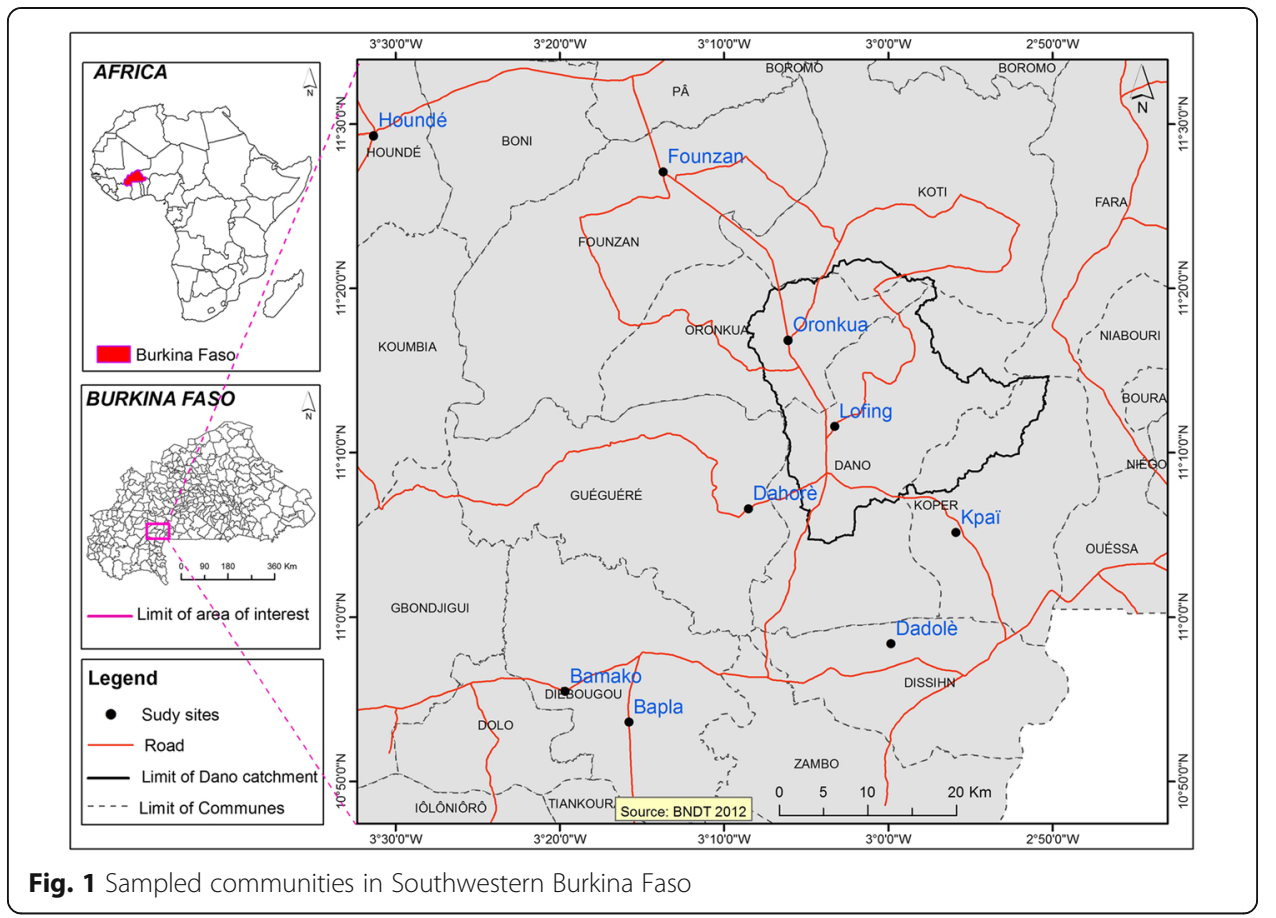

In case the disaster is not officially recognized, you will not be compensated. However, if there is a dry spell disaster and you claim compensation, an insurance expert will visit your farm and assess the extent of the crop damage. Based on his or her independent assessment, you will be compensated accordingly, up to the maximum of your insurance sum and contract, terms and conditions of which are protected by law.

The respondents were then presented with a DC elicitation question buttressed with an OE follow-up elicitation questions. First, the respondents were asked whether they are willing to participate in the new index-based crop insurance pilot initiative. Those who said 'yes' to this initial question were then asked how much they would like to pay for their most preferred crop insurance product and coverage and how they will like to pay (i.e., cash or kind). Second, the valuation question was then introduced after this, asking respondents for a monthly insurance premium ranging between 2538 FCFA (US\$ 5.1) and 17,500 FCFA (US\$ 35.0). If the respondent said yes to the initial bid offer, a follow-up question was then asked, to elicit the respondent's maximum WTP amount. However, if the answer was no, another follow-up question was asked, to find out the reason for the refusal to pay.

Prior to the actual survey, an official debriefing session was held with the Director of the 'Direction Provincial de Agriculture' in the region. The aim was to explain the purpose of our field visits, solicit for assistance in setting up meetings with farmers, and identify contact persons in each community to facilitate the FGDs. Ten graduate students from the University of Ouagadougou were trained on each topic of the household questionnaire comprising of six sections (household education, consumption, employment, perception of climate risk or hazards, climate manifestation on farmlands, and risk management strategies). The enumerators were instructed to interview only the household heads defined as the breadwinner or the economic head of the family. However, in cases 
where household heads were not available, repeated visits were made or in rare cases the spouse or next eldest person in the household was interviewed. Overall, a total of 267 farmers were randomly selected in the 10 sampled communities. This formed the appropriate minimum sample required for the study based on the Taro Yamane specification with a 5\% margin of error (Yamane 1967).

\section{Results}

\section{Sample statistics}

Table 2 provides the description of variables used in the analysis. As shown (Table 2), 88\% (235 respondents) had positive WTP values for the new crop insurance scheme. However, in terms of household characteristics, the average household size was about 11. Most of the household heads interviewed (98\%) were farmers although about 57\% were also engaged in off-farming activities such as petty-trading and craftsmanship. The average household per capita income for the sample was calculated as 163,533 FCFA or about US\$327.1 per annum or 13,627.75 FCFA (US\$ 27.3) per month. Close to $92 \%$ were male-headed households while the average age was about 46 years. In terms of years of schooling, the average was about 2.6 years. Also, the average number of years devoted to farming was about 31 years while the average household farm size was about 1.6 hectares. In terms of social capital, defined as support from group membership or any form of support received from friends or relatives to cope with climate changerelated risks, about 39\% acknowledged having received support in the last 12 months prior to the survey. Equally, more than $63 \%$ of the sample reported making use of crop diversification as an important climate change adaptation strategy.

Furthermore, about $43 \%$ of the households acknowledged making use of supplementary irrigation techniques. Households with access to any form of credit facilities (formal) were less than $11 \%$. Further, more than $69 \%$ of the respondents were very knowledgeable about climate change risks of which more than $87 \%$ reported having suffered from at least one episode of climate disaster in the last 12 months. The average cost of an episode of climate damage per farm hectare per annum was estimated as 194,832.3 FCFA or about US\$ 389.67. Further still, only about 32\% of the respondents reported having basic knowledge about crop insurance in general. In terms of previous participation in any crop insurance management initiative, less than $5 \%$ indicated having participated in the past. Finally, more than $77 \%$ expressed confidence in microfinance institutions as appropriate fund managers for the scheme.

\section{Determinants of WTP for the scheme}

Here we focus our attention to the econometric analysis of the determinants of WTP for the scheme. First, it is useful to distinguish between responses that can be considered valid and those that appear 'invalid' in the analysis. Out of the 267 completed interviews, 32 respondents (12\%) were considered to have invalid responses to the valuation question. The main reasons for such invalid responses were protest bidders (13) and outliers (19). Protest respondents were those who said they cannot afford to pay for the scheme due to cash constraints (3), those who said the scheme was not important to them (5), as well as those who said they will wait for the government (5). Outliers, on the other hand, were those whose maximum WTP amounts were more than $5 \%$ of their income (8), including 
those who accepted the initial start bid proposed but reported a significantly lower amount in the OE follow-up elicitation question (11).

Based on this, it was necessary to find out whether excluding invalid responses from the econometric analysis would lead to a sample selection bias problem, which may have two likely consequences as highlighted in Mekonnen (2000). First, testing for theoretical validity using the valuation function in the empirical analysis may generate inconsistent parameter estimates similar to those stated in Heckman (1977) or Maddala (1983). Second, the estimated benefit measures and hence the aggregated WTP values may also be biased. As discussed in Mekonnen (2000), Strazzera et al. (2003), Fonta and Ayuk (2013), and Fonta et al. (2012), a preliminary test for the presence of sample selection bias is to test for the differences in the means of household covariates between the two groups. Any significant difference is a potential indicator of the presence of sample selection bias. For most of the considered variables shown in Table 3, there were no significant differences between the two groups of respondents except for the variable 'Access to irrigation' for which the difference is found to be statistically significant at a $10 \%$ level. Furthermore, the t-test of the coefficient of $\lambda$ in the regression equations with a value of -0.82 in Table 4 is not significantly different from 0 . These findings reinforce the absence of a sample selection bias problem when invalid responses are excluded from the econometric analysis.

The econometric results based on Heckman 2-step estimator are presented in Table 4. However, note that the table reports the parameter estimates for the best-fit specifications (i.e., most valid reduced form models) from the two equations (i.e., participation and valuation) selected by means of likelihood ratio (LR) tests.

Starting first with the probit regression estimates (Eq. 6), there are some statistically significant coefficients in the participation model. These identified variables depict certain aspects of the sample that influence a household decision to participate in the index-based crop insurance scheme. Among the identified variables, the amount an individual is asked to pay (i.e., the starting price), the age group of a respondent, access to formal credit facilities, households that make frequent use of supplementary irrigation techniques, the cost associated with managing climate risk at farmlands, being engaged in crop diversification, being a past victim of climate hazard, having knowledge about crop insurance in general, as well as household income play a significant role in the households' decision to participate in crop insurance.

Table 3 Comparison of means for 'valid/invalid' WTP responses

\begin{tabular}{|c|c|c|c|c|c|}
\hline \multirow[b]{2}{*}{ Variable } & \multicolumn{2}{|c|}{ Positive WTP responses } & \multicolumn{2}{|c|}{ Invalid WTP responses } & \multirow[b]{2}{*}{ t-stat } \\
\hline & Coef. & Std. Err. & Coef. & Std. Err. & \\
\hline Age & 46.1 & 0.933 & 50.2 & 2.022 & -1.53 \\
\hline Access_irrigation & 0.42 & 0.03 & 0.55 & 0.091 & $-1.98^{*}$ \\
\hline Education & 2.7 & 0.246 & 2.5 & 0.680 & 0.24 \\
\hline Farm_activities & 1.0 & 0.006 & 1.0 & 0.032 & 1.18 \\
\hline Farming_expirience & 31.0 & 0.988 & 32.2 & 2.693 & -0.41 \\
\hline Gender & 0.92 & 0.017 & 0.90 & 0.054 & 0.39 \\
\hline Household_income & $165,317.0$ & $10,437.1$ & $150,179.8$ & $28,728.6$ & 0.50 \\
\hline Household_size & 11.7 & 0.708 & 11.2 & 1.190 & 0.29 \\
\hline
\end{tabular}


Table 4 Modeling results from Heckman's 2-step estimation procedure

\begin{tabular}{|c|c|c|c|c|c|c|}
\hline \multirow[b]{3}{*}{ Variable } & \multicolumn{3}{|c|}{ Probit estimate (first-stage equation) } & \multicolumn{3}{|c|}{ OLS estimates (primary equation) } \\
\hline & \multicolumn{3}{|c|}{ Participation model } & \multicolumn{3}{|c|}{ Valuation model } \\
\hline & Coef. & Std. Err. & z -value & Coef. & Std. Err. & t -value \\
\hline Constant & 1.101 & 0.921 & 1.20 & 4.656 & 4.846 & 0.96 \\
\hline Starting_bid & -0.00016 & 0.00003 & $-4.74^{* * *}$ & & & \\
\hline \multicolumn{7}{|l|}{ Age (young adults) } \\
\hline Middle age & -1.372 & 0.554 & $-2.47^{* *}$ & & & \\
\hline Elderly age & -2.685 & 0.877 & $-3.06^{* * *}$ & & & \\
\hline Access_credit & 0.276 & 0.003 & $3.18^{* * *}$ & & & \\
\hline Access_irrigation & -2.431 & 0.988 & $-2.46^{* *}$ & & & \\
\hline Cost_damage & 0.318 & 0.146 & $2.17^{*}$ & & & \\
\hline Crop_diversity & 0.235 & 0.091 & $2.57^{* *}$ & & & \\
\hline \multicolumn{7}{|l|}{ Education (no formal) } \\
\hline Primary education & & & & 0.981 & 0.429 & $2.29^{* *}$ \\
\hline Secondary education & & & & -0.265 & 0.429 & -0.62 \\
\hline Tertiary education & & & & -5.438 & 22.266 & -0.24 \\
\hline Farming_expirience & 0.027 & 0.013 & $2.08^{*}$ & & & \\
\hline Farm_size & & & & 0.889 & 0.389 & $2.28^{* *}$ \\
\hline Gender & & & & -0.727 & 0.365 & $-2.17^{* *}$ \\
\hline Hazard_expirience & 1.412 & 0.396 & $3.57^{* * *}$ & & & \\
\hline \multicolumn{7}{|l|}{ Income (low) } \\
\hline Middle income & 0.316 & 0.127 & $2.50^{* *}$ & 0.087 & 0.020 & $4.31^{* * *}$ \\
\hline High income & -0.595 & 0.440 & -1.35 & -0.322 & 0.262 & -1.23 \\
\hline Knowlwdgeable_insurance & 0.911 & 0.317 & $2.87^{* * *}$ & & & \\
\hline Knowledgeable_risk & & & & 0.582 & 0.230 & $2.53^{* *}$ \\
\hline Rho $(\rho)$ & -0.224 & 0.274 & -0.82 & & & \\
\hline Sigma $(\sigma)$ & 6.57 & 0.35 & $18.78^{* * *}$ & & & \\
\hline Lambda $(\lambda)$ & -0.147 & 0.182 & -0.81 & & & \\
\hline Log-likelihood & & & -1944.5 & & & \\
\hline Obs. & & & 267 & & & 235 \\
\hline
\end{tabular}

Significance of parameters ${ }^{* *}<0.01, * *<0.05,{ }^{*}<0.10$

Taking a look at the results, the effect of the amount the individual is asked to pay for the scheme (i.e., the starting price) is negative, implying that higher amounts discourage farmers and seem to induce a lower propensity to participating in the insurance scheme. This may be due to the differential existing between the proposed bid amount and the individual's true reservation price for the scheme. This is an important finding because the amount of premium might be the key impediment to participating in index-based crop insurance schemes in developing country settings. This has an important policy implication for governments (e.g., providing subsidy and other support) that introduces the initiatives to support the agricultural sector. Also, the age group to which an individual belongs has an effect on the decision to participate. In particular, individuals that fall within the middle age group (i.e., 36-59 years) are, on average, 1.4 times more likely to participate in crop insurance than the young adults (i.e., 22-35 years). The same can be said about the elderly (i.e., 60 and above years): they are 2.4 times less likely to participate than the young adults. Subsistence 
agriculture is very strenuous thus, other things remaining constant, with more ageing, the less likely one will be actively involved in agriculture. This may explain why the participation rate drops with increasing age. In addition, older farmers might have a lower level of trust toward modern insurance products compared to middle-aged or young farmers. The same can be said about having more access to supplementary irrigation land or technology. The more access an individual has, the lower the participation rate. This is possibly due to the fact that such households have more access to water to support crops during dry spells. In fact, McCarthy (2003) also found a negative correlation between access to irrigated land and the demand for crop insurance in Morocco.

On the other hand, having more access to formal credit increases the tendency to participate in crop insurance uptake. Formal finance (e.g., at commercial banks) can complement informal finance, which is often commonly used to handle agricultural shocks in the developing world. In fact, this is expected as the ongoing pilot insurance scheme in Burkina Faso is essentially credit-based by design. Crop diversification also revealed a similar effect on a farmer's decision to participate in the pilot scheme. In particular, the positive coefficient implies that the greater the crop diversity, the higher the participation rate. This is so because crop diversification reflects a key risk management strategy to climate change in the Sahel. The same can be said about farmers that were past victims of a climate change event. They have a higher propensity to participate than nonvictim farmers, possibly because of the high associated cost incurred in managing such an event experienced previously. In fact, McCarthy (2003) found that the demand for crop insurance is higher where risk management and/or coping mechanisms are relatively more costly. Also, knowledge about crop insurance schemes equally had a positive effect on a household's decision to participate. As explained by Skees et al. (2001), the decision to use insurance is highly dependent on farmers' understanding of the insurance product. It is therefore not surprising that farmers who are better informed about crop insurance are more willing to participate in the new pilot initiative. Finally, income has a positive effect in crop insurance participation rate; the higher the income, the higher the probability of participation. Clearly, richer households have a stronger ability to pay (ATP) for insurance contracts especially at the beginning of the planting season, when cash flows are generally tightest. As reported in Table 4, the highest income earners were, on average, 0.59 times more willing to participate than the lowest income earners. This does not mean that policies should focus on those who have a higher willingness to pay. Rather, this gives an indication that poor farmers should be targeted in using affordable premium crop insurance initiatives. This allows poor farmers with access to the best possible cover for potential risks.

In the censored regression where WTP $>0$ is the dependent variable, again the coefficient on household income was significant and positive. This implies that wealthier households are willing to pay more for the scheme than their poorer counterparts (presumably for the same reason that they are also more willing to participate in the scheme). The results further reveal that more educated farm household heads reported lower WTP amounts than their less educated counterparts. For instance, those with tertiary education are, on average, 5.4 times less willing to pay for the scheme than farm household heads with no formal education. One plausible explanation for this is that farmers who are better educated are likely to have better access to formal credit facilities and to irrigated 
crop lands. This may explain why educated household heads have lower demand for crop insurance than the less educated ones. Furthermore, the results suggest that farm households with larger farm size holding are willing to pay more for the scheme than households with small farm sizes. The obvious reason for this is wealth. There is more at stake for wealthier farmers than poor farmers if dry spells and other natural disasters are encountered. It is evident that farmers with large farms have more crops to insure than those with smaller plots.

Higher WTP amounts were associated with male-headed farm households relative to female-headed households. This may be linked to the household decision-making process in the context of Burkina Faso. Males are usually responsible for all major household decisions, including making insurance payments. Finally, households who are better informed about the risk of climate change to agriculture expressed higher demand for the scheme than the less knowledgeable households. This may be due to the fact that such households are aware of the higher relative costs associated with managing climate change risk as well as to cope with the consequences.

\section{WTP predictions}

Based on the fact that there is no significant evidence of sample selection bias, the modeling results for the subsample of valid responses (OLS results) were used to predict the mean WTP value for the crop insurance pilot initiative in Southwestern Burkina Faso. The predicted results are shown in Table 5. Mean WTP for the sampled households is estimated as 7142 FCFA or US\$14.3 monthly with interval estimates of 6239 FCFA (US\$12.5) and 8045 FCFA (US\$16.1), respectively. This estimate seems intuitively reasonable when compared with the credit-based crop insurance scheme in Zambia where farmers pay an equivalent membership fee of US $\$ 10$ (van Asseldonk et al. 2013). However, our estimate is slightly lower when compared to what is currently being charged in Senegal. The cost of the premium of an insurance system in Senegal varies from 14,000 FCFA (US\$23.3) to 20,000 FCFA (US\$33.3), respectively. This is of course attributed to different product coverage and the insurance contracts used.

It is important to emphasize the fact that the ongoing crop insurance pilot in Burkina Faso has no standardized procedure for designing and charging insurance premiums to reflect fairness and equity in the pricing decision. It has been greatly criticized for inducing unfair differences in protection level between areas as well as failing to account for sensitive phases of the crops (Muller 2012). The predicted WTP estimate obtained in our study offers an important starting point for the pricing decision of the scheme.

Despite the interesting results discussed above, it is important to highlight a number of limitations that are associated with the current application. The study uses a WTP approach. Although the WTP approach proved quite useful and highly relevant under the socioeconomic and farming practice conditions in Burkina Faso, it is important to

Table 5 Summary statistics of monthly mean WTP bid ${ }^{\mathrm{a}}$

\begin{tabular}{llll}
\hline Model & Obs. & Mean & Cl-mean (95\%) \\
\hline OLS & 235 & $7141.69(14.3)$ & $6238.68(12.5)-8044.71(16.1)$ \\
\hline
\end{tabular}

${ }^{a}$ All figures presented as West African CFA (\$US)

${ }^{b}$ Normal-based $95 \%$ confidence interval generated with Bootstrap replications 
acknowledge the fact that other alternative methods of analysis exist in the literature. These alternatives might have yielded slightly different modeling results. For instance, to evaluate the extent to which farmers value index-based crop insurance, alternative approaches have used role-playing games (Patt et al. 2006; Patt et al. 2010; Peterson and Mullally 2009). Simulation games provide farmers with first-hand experience over the potential implications of having an insurance scheme. Simulation games enhance communication and opportunity for experimental learning between farmers and potential insurance companies. Beyond game-related simulations, additional methods involve experimental and quasiexperimental studies that estimate the factors that drive participations in index-based insurance schemes (Takahashi et al. 2016; Serfilippi et al. 2015).

Another limitation relates to our exclusive focus on index-based insurance, despite the existence of a variety of insurance schemes available to farmers, to mitigate either input or production-related risks. Different risk management options are available to farmers in the developing world and insurance is only one of these risk management options. Moreover, agriculture insurance can even take different forms such as yield and revenue insurance, commodity price insurance, weather insurance, etc. Nevertheless, beyond insurance schemes, farmers have various alternative ways that can be used to manage risks. These include crop diversification and spatial diversification that involve farming in alternative lands with different soil characteristics, self-insurance, and the use of pesticides, herbicides, and other modern input-based means of controlling production risks. Finally, it is important to highlight on the critical importance of peers or family members to mitigate risks in an African context. When farmers can rely on their relatives to mitigate their risks, evidence show that this tends to reduce vulnerability within the community (Udry 1994; Fafchamps and Gubert 2007; Fafchamps and Lund 2003). Hence, in developing countries such as Burkina Faso, one might expect limited propensity and low participation in formal index-based insurance schemes.

\section{Conclusion}

Weather index-based crop insurance represents a very promising agricultural risk management strategy that farmers may use to mitigate adverse climate hazards and natural catastrophes encountered during farming activities. In many parts of the world, implementation of such crop insurance policies have allowed for consistent support to farmers to limit the losses that natural calamities like droughts, flood, variabilities in rainfall and/or temperature, dry spells, hail, and heat waves might cause to crop yields and income. It has several advantages in that it minimizes both moral hazard and adverse selection and it makes faster payouts during natural disasters, which means that farmers will not have to sell assets or depend on emergency food aid to survive. In addition, crop insurance encourages more investment in agricultural inputs leading to higher outputs and income per unit of land, and it enhances farmers' resilience to bouts of recurrent food insecurity. Overall, it is vital to get households out of poverty.

Unfortunately, index-based crop insurance has not made significant uptake and progress in Africa. While Europe, North America, and Asia account for 20.1\%, 55\%, and 19.5\%, respectively, of the total agricultural insurance premium worldwide, Africa accounts for only $0.5 \%$ of the world insurance industry (World Bank 2009). Of the few existing pilots, especially those in West Africa, the coverage and uptake are still very low. Although no consensus has emerged as to why this is so, one of the foremost reasons given is the lack 
of stakeholders engagement and involvement in the initial conceptualization and design of the proposed schemes.

The main purpose of this study was, therefore, to shed more light on the role of stakeholders' involvement (participation) in designing successful weather index-based crop insurance pilots in rural West Africa. We used as a case study the southwestern region, Burkina Faso, where a new crop insurance management initiative is being proposed by PlaNet Guarantee. In the application context, we find that integrating stakeholders' opinion at the initial onset of the scheme can go a long way to increase participation and hence uptake. The results further suggest that analysis of the bid function can provide very useful qualitative and quantitative information, which is difficult to identify using alternative economic evaluation techniques. For instance, the empirical findings indicate that the amount charged as insurance premium and the frequency of payments significantly affect weather index-based crop insurance coverage and uptake. Higher amounts seem to discourage participation and take-up. Similarly, the more informed consumers are about crop insurance, the greater their chances of participating and the higher their demand. Interestingly, the results also reveal that households with more access to formal credit facilities showed higher participation and greater take-up rates. More interestingly and unsurprisingly, the results show that income is perhaps the most significant determinant for the demand of index-based crop insurance in general.

In light of the above findings, five important policy recommendations can be proposed. Firstly, in terms of participation and coverage, it may be necessary to split the insurance premium into very little amounts that can be more frequently and manageably paid by farm households. Secondly, increasing awareness of this type of crop insurance through public education and enlightenment campaigns will go a long way to increasing coverage and uptake. Thirdly, encouraging programs that are tailored toward improving farm households' access to credit facilities would play a vital role in increasing crop insurance participation and coverage in the region. This can be done by complementing informal and semiformal financial sources. Fourthly, investing in irrigation (an untapped potential in much of Africa) will, in the long run, support local farmers to cope with climate change uncertainty. Finally, policy should target poor famers so that they will have the necessary financial funds in place (e.g., conditional cash transfer and income support) so that they benefit from crop insurance schemes that can buffer them from shocks that lead to crop failure.

\section{Acknowledgments}

The authors gratefully acknowledge the University Meets Microfinance (UMM) and the African Development Bank (AfDB) for recognizing the potential in this work and for honoring it with one of the two Making Finance Work for Africa (MFW4A) Awards. Our special appreciation goes to Planet Guarantee and all participants of the dissemination workshop held in Ouagadougou on September 5, 2014. The excellent research support from our field staff including excellent comments and suggestions from two anonymous referees, John P. Lamers, Julia Kloos, Marc Muller, Ahmadou Dicko, Gerald Forkuor, Simona Bigerna, Boubacar Barry, Boubacar Ibrahim, Karen Greenough and Cynthia Fonta, are gratefully acknowledged. The usual disclaimer applies. 


\section{Authors' contributions}

WMF and SS conceptualized and coordinated the study including the design and supervision of the field survey. WMF performed the data analysis and the interpretation of the model results. WMF, SS, AMK, and DRT wrote the manuscript. All the authors read and approved the final manuscript.

\section{Authors' information}

William M. Fonta is the Senior Resource Economist for the West African Science Service Center on Climate Change and Adapted Land Use (WASCAL) located in Ouagadougou, Burkina Faso, West Africa. His main research interests are environmental and resource economics, green economics, public economics, development economics, and demography.

Sanfo Safiétou is an agricultural economist with WASCAL. Her research interests include bioeconomic modeling, climate change, rural household livelihood and food security, environmental migration, and agricultural risk management strategies.

Abbi M. Kedir is a Senior Lecturer in International Business, Sheffield University Management School, University of

Sheffield, UK. As quantitative development economist, his research interests are agricultural finance, international trade, foreign direct investment, firm performance, poverty, labor markets, and public policy.

Djiby Racine Thiam is Senior Lecturer at the School of Economics, University of Cape town, South Africa. His main research interests are natural resources and environmental economics, development economics, agricultural economics, and public policy.

\section{Competing interests}

The authors declare that they have no competing interests.

\section{Publisher's Note}

Springer Nature remains neutral with regard to jurisdictional claims in published maps and institutional affiliations.

\section{Author details}

${ }^{1}$ West African Science Service Centre on Climate Change and Adapted Land Use (WASCAL), Competence Center, Blvd Mouammar Kadhafi, 06, Ouagadougou, BP 9507, Burkina Faso. ²University of Sheffield Management School, Sheffield,

UK. ${ }^{3}$ School of Economics, University of Cape Town, Cape Town, South Africa.

\section{Received: 17 May 2017 Accepted: 19 April 2018}

Published online: 14 June 2018

\section{References}

Arrow K, Solow R, Portney PR, Leamer EE, Radner R, Schuman H (1993) Report of the NOAA panel on contingent valuation. Fed Regist 58:4601-4614

Barnett B (2014) Multiple-peril crop insurance: successes and challenges. Agric Finance Rev 74:200-216

Barnett BJ, Mahul O (2007) Weather index insurance for agriculture and rural areas in lower-income countries. Am J Agric Econ 89:1241-1247

Barnett BJ, Barrett CB, Skees JR (2008) Poverty traps and index-based risk transfer products. World Dev 36:1766-1785

Berg A, Quirion P, Sultan B (2009) Weather-index drought insurance in Burkina-Faso: assessment of its potential interest to farmers using historical data. Weather Clim Soc Prepr 20090000

CCAFS (2014) Weather index-based insurance: a tool for managing climate risk. https://ccafs.cgiar.org/themes/indexbased-insurance. Accessed 29 Oct 2014

Chambers RG (1989) Insurability and moral hazard in agricultural insurance markets. Am J Agric Econ 71:604-616

Clarke D, Dercon S (2009) Insurance, credit and safety nets for the poor in a world of risk. United Nations Department of Economics and Social Affairs Working Paper 81. United Nations, Washington, DC

Cole S, Jagnani M, Nestor L, Tobacman J (2013) Marketing weather-indexed agricultural insurance to smallholder farmers in rural Gujarat, India. Int Growth Cent Policy Brief 13:0880

De Bock O, Gelade W (2012) The demand for microinsurance: a literature review. ILO, Geneva Microinsurance Innov Facil Res Pap

Dercon S, Christiaensen L (2011) Consumption risk, technology adoption and poverty traps: evidence from Ethiopia. J Dev Econ 96:159-173

Devereux S, Guenther B (2009) Agriculture and social protection in Ethiopia, growth and social protection. Working paper 03, Future Agricultures and Centre for Social Protections, Nairobi

Duncan J. Myers R (2000) Crop insurance under catastrophic risk. Am J Agric Econ 82(4):842-855

Fafchamps M (2010) Vulnerability, risk management, and agricultural development. Afr J Agric Econ 5:243-260

Fafchamps M, Gubert F (2007) The formation of risk sharing networks. J Dev Econ 83:326-350

Fafchamps M, Lund S (2003) Risk-sharing networks in rural Philippines. J Dev Econ 71:261-287

FAO (2011) Agricultural insurance in Asia and the Pacific Region. RAP Publication 2011/12. FAO, Rome

Fonta WM, Ayuk ET (2013) Measuring the role of forest income in mitigating poverty and inequality: evidence from South-Eastern Nigeria. For Trees Livelihoods 22:86-105

Fonta WM, Ichoku EH, Ataguba JE (2010a) Paying for community-based health insurance schemes in rural Nigeria: the use of in-kind payments. Afr Rev Money Finance Bank: 109-128

Fonta WM, Ichoku EH, Kabubo-Mariara J (2010b) The effect of protest zeros on estimates of willingness to pay in healthcare contingent valuation analysis. Appl Health Econ Health Policy 8:225-237

Fonta MW, Ayuk ET, Ichoku EH (2012) Simple sequential guidelines for modelling of item non-response in econometric analysis: application to CV survey data. J Appl Stat 3(1):1-16 
Fonta MW, Sawadogo M, Atewamba C, Kouame EBH (2017) Country profile on climate change, agricultural trade and food security in ECOWAS: Burkina Faso Report. UNU-INRA Working Paper (in press)

Freeman AM (1992) The measurement of environmental and resource values: theory and methods. Resources for the Future, Washington, DC

Fuchs A, Wolff H (2011) Concept and unintended consequences of weather index insurance: the case of Mexico. Am J Agric Econ 93:505-511

Giné X, Yang D (2009) Insurance, credit, and technology adoption: field experimental evidence from Malawi. J Dev Econ 89:1-11

Giné X, Menand L, Townsend R, Vickery J (2008) Microinsurance: a case study of the Indian rainfall index insurance market. World Bank, Washington, DC

Greene WH (1993) Econometric analysis. Pearson Education Inc, Singapore

Haab TC, McConnell EK (2002) Valuing environmental and natural resources: the econometrics on non-market valuation. Edward Elgar Publishing Ltd, Cheltenham

Heckman JJ (1977) Sample selection bias as a specification error (with an application to the estimation of labor supply functions). National Bureau of Economic Research, Cambridge, MA

Ibrahim B, Karambiri H, Polcher J, Yacouba H, Ribstein P (2014) Changes in rainfall regime over Burkina Faso under the climate change conditions simulated by 5 regional climate models. Clim Dyn 42:1363-1381

IFAD (2011) Weather index-based insurance in agricultural development: a technical guide, IFAD-WFP Weather Risk Management Facility (WRMF). International Fund for Agricultural Development, Rome

IPCC (2014) Climate Change 2014: Synthesis report and summary for policymakers, Intergovernmental Panel on Climate Change. http://www.ipcc.ch/pdf/assessment-report/ar5/syr/AR5_SYR_FINAL_SPM.pdf. Accessed 21 July 2015

Janzen SA, Carter MR, lkegami M (2013) Valuing asset insurance in the presence of poverty traps, Working paper. University of Columbia, Davis

Jensen N, Barrett C (2016) Agricultural index insurance for development. Appl Econ Perspect Policy 39:199-219

Kapphan I (2011) Optimal weather insurance design - a quantitative exploration. Paper presented at the Modelling and Simulation Society of Australia and New Zealand (MSSANZ), Perth, May 2011

Karlan D, Osei R, Osei-Akoto I, Udry C (2014) Agricultural decisions after relaxing credit and risk constraints. Q J Econ 129:597-652

Köhlin G (2001) Contingent valuation in project planning and evaluation: the case of social forestry in Orissa, India. Environ Dev Econ 6:237-258

Koloma Y (2015) Crop microinsurance for maize farmers in Burkina Faso: access and agriculture performance in the Dandé village. Strateg Chang 24:115-129

Kunreuther H (1996) Mitigating disaster losses through insurance. J Risk Uncertain 12:171-187

Kurukulasuriya P, Mendelsohn R (2008) A Ricardian analysis of the impact of climate change on African cropland. Afr J Agric Resour Econ 2:1-23

Maddala GS (1983) Limited-dependent variables and qualitative variables in econometrics. Cambridge University Press, Cambridge

Mahul O, Skees JR (2007) Managing agricultural risk at the country level. World Bank Publications, New York

Mahul O, Stutley CJ (2010) Government support to agricultural insurance: challenges and options for developing countries. World Bank Publications, New York

Mas-Colell A, Whinston MD, Green JR (1995) Microeconomic theory. Oxford University Press, New York

McCarthy NA (2003) Demand for rainfall-index based insurance: a case study from Morocco, EPTD discussion paper no. 106. International Food Policy Research Institute, Washington, DC

Mekonnen A (2000) Valuation of community forestry in Ethiopia: a contingent valuation study of rural households. Environ Dev Econ 5:289-308

Mills E (2007) Synergisms between climate change mitigation and adaptation: an insurance perspective. Mitig Adapt Strateg Glob Chang 12:809-842

Miranda MJ (1991) Area-yield crop insurance reconsidered. Am J Agric Econ 73:233-242

Mitchell RC, Carson RT (1989) Using surveys to value public goods: the contingent valuation method. Resources for the Future, Washington, DC

Muller B (2012) Index based crop insurance in Senegal and West Africa: some concerns based on on-going experiments. https://afrique-ouest.cirad.fr/content/download/6398/59957/version/1/file/obj_5048_file_obj_7951_ file_JRC_IRI_Muller_2012_final.pdf. Accessed 4 June 2014

Patt AG, Bowles HR, Cash DW (2006) Mechanisms for enhancing the credibility of an adviser: prepayment and aligned incentives. J Behav Decis Mak 19:347-359

Patt A, Suarez P, Hess U (2010) How do small-holder farmers understand insurance, and how much do they want it? Evidence from Africa. Glob Environ Chang 20:153-161

Peterson N, Mullally C (2009) Index insurance games in Adi Ha Tabia, Tigray regional state, Ethiopia. Oxfam America, Boston

Planet Guarantee (2014) Assurer nos récoltes c'est garantir notre production. Newsletter Assurance Récolte Sahel 1, Dakar

Planet Guarantee (2015) Creating opportunity where it's needed most. http://www.ifc.org/wps/connect/indudtry_ext_ content/ifc_external_corporate_site/ind. Accessed 10 Oct 2015

Sarris A, Krfakis P, Christiansen L (2006) Producer demand and welfare benefits of rainfall insurance in Tanzania. Working paper 18. FAO Commodity and Trade Policy, Rome

Serfilippi E, Carter M, Guirkinger C (2015) Certain and uncertain utility and insurance demand: results from a framed field experiment in Burkina Faso. Paper presented at the International Association of Agricultural Economists conference, Milan, 9-14 Aug 2015

Smith VH, Glauber JW (2012) Agricultural insurance in developed countries: where have we been and where are we going? Appl Econ Perspect Policy 34:363-390

Smith HV, Watts M (2014) Index-based agricultural insurance in developing countries: feasibility, scalability and sustainability. https:/ag4impact.org/publications/montpellier-panel-report2013/. Accessed 10 June 2014 
Strazzera E, Genius M, Scarpa R, Hutchinson G (2003) The effect of protest votes on the estimates of WTP for use values of recreational sites. Environ Resour Econ 25:461-476

Sundar J, Ramakrishnan L (2013) A study on farmers' awareness, perception and willing to join and pay for crop insurance. Int J Bus Manag Invent 2:48-54

Takahashi K, Ikegami M, Sheahan M, Barrett CB (2016) Experimental evidence on the drivers of index-based livestock insurance demand in Southern Ethiopia. World Dev 78:324-340

The Montpellier Panel (2013) Sustainable intensification: a new paradigm for African agriculture, London. https:// ag4impact.org/publications/montpellier-panel-report2013/. Accessed 20 June 2014

Tucker M (1997) Climate change and the insurance industry: the cost of increased risk and the impetus for action. Ecol Econ 22:85-96

Udry C (1994) Risk and insurance in a rural credit market: an empirical investigation in northern Nigeria. Rev Econ Stud 61:495-526

Van Asseldonk M, Burger CPJ, Maïtre d'Hotel E, Muller B, Le Cotty T, Meijerink GW (2013) Linking crop insurance and rural credit, LEI WUR/FaRMAf' project report. Farm Risk Management for Africa, London

Varian HR (1992) Microeconomic analysis. WW Norton, New York

WASCAL (2015) Research science plan 2017-2020. West African Science Service Centre on Climate Change and Adapted Land Use, Ouagadougou

World Bank (2005) Managing agricultural production risk: innovations in developing countries. Agriculture and Rural Development Department (ARD) World Bank, Washington, DC

Yamane T (ed) (1967) Statistics: an introductory analysis. Harper \& Row, New York

Submit your manuscript to a SpringerOpen ${ }^{\circ}$ journal and benefit from:

- Convenient online submission

- Rigorous peer review

- Open access: articles freely available online

- High visibility within the field

Retaining the copyright to your article

Submit your next manuscript at $\gg$ springeropen.com 